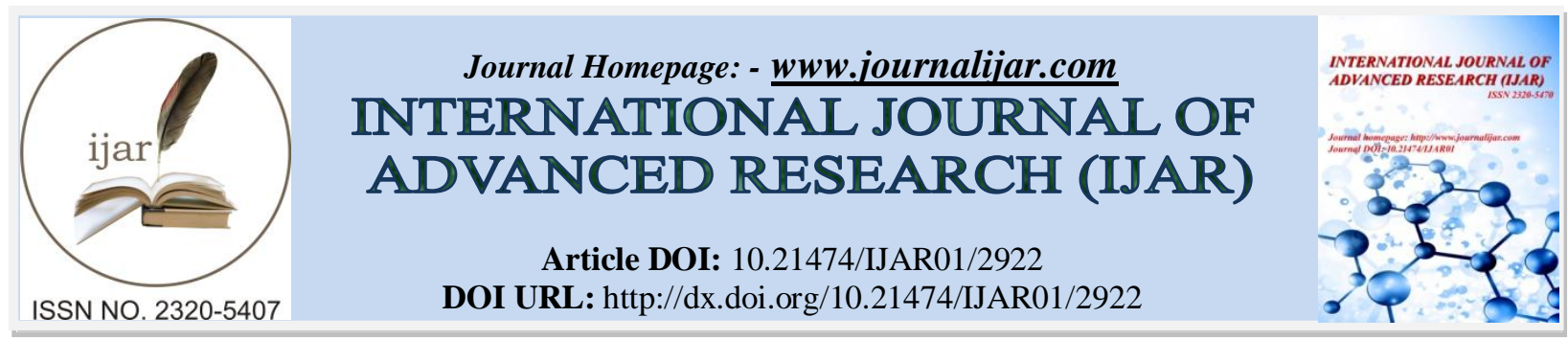

RESEARCH ARTICLE

\title{
THE DRAMA OF AUGUST WILSON: FENCING A NEW IDENTITY IN AFRICAN AMERICAN THEATRICAL IMAGINATION.
}

Kouame Sayni.

Maitre-Assistant, Université Alassane Ouattara, Bouake.

\section{Manuscript Info}

Manuscript History

Received: 24 November 2016

Final Accepted: 25 December 2016

Published: January 2017

Key words:-

identity, drama, sport, music, responsibility, work, ancestral heritage, etc.

\section{Abstract}

What is the image of the Black in contemporary American society, and how is it represented in drama, a form of artistic expression where African American voice has long been silenced by stereotypes and editorial marginality? This is the question which black playwright August Wilson tries to answer in an unusual theatrical production. Gifted with a talent for catching dialect and accents, which ironically contributed to fight down his image and voice in American drama, Wilson enriches his pieces with his poetical skills he learned to use in his early days as artist. He notably shows that the African American destiny is open to other possibilities than what the racist society offered. More specifically in Fences (1986), he shows that the African American can find wholeness if he accepts to work hard and uses his rich cultural heritage. These, he says, are what will make him a responsible person.

Copy Right, IJAR, 2016,. All rights reserved.

\section{Introduction:-}

Poet, essayist, multiple-prize winner including the Pulitzer Prize, Bush, McKnight, Rockefeller, and Guggenheim Foundation fellowship in playwriting, most of the adepts in African American literature present August Wilson as the first American playwright of African descent to have two plays running simultaneously on Broadway in late 1980s. And yet, nothing would have permitted to imagine African American drama at such a high level, at least before 1923 when a play produced by an African American playwright got performed in Broadway. As I have mentioned in a precedent work, a number of historical factors acted as hindrance to African American theatrical creativity. Among these, we have slavery and the conditions implied by it, that is, racist marginalization, lack of financial and editorial supports, and the stereotypes implied by the nature of drama as a genre used by white mainstream theatre to denigrate the image of the Black through minstrelsy and dialect poetry ${ }^{1}$. With an artistry which came to age in the 1970s and 1980s, Wilson has brought his work out of these mockeries and limitations; more than that, it has given a revitalized expression to black theatrical performance.

How significant is Drama to August Wilson who is reported to have started his literary career in poetry? What are the main issues developed in his work, and how does this personal artistry contribute to the enhancement of the African American in American theatrical development?

1 - For further details on the African American's participation to American drama see: Kouamé SAYNI, "The African American Theatrical Expression in the USA: A Crippled Quest for Identity", Particip'Action, Vol 9, Janvier 2017 (97-110) 
This paper is an evaluation of African American drama through the work produced by August Wilson; it is the second of this kind of exercise which is meant to examine the development of American theatre in general, and African American play writing in particular with a focus on Fences (1986), Wilson's second major play. Fences (1986) tells the story of Troy Maxson, an ex-baseball player who is now obliged to work as a garbage collector because of the racism which crushed his dream of success in sports. Frustrated, he has decided to reshape the life of his family within the limits of a fence he wants to build to keep his household from the harm of society. In our work, we will first make an overview of Wilson's literary career, and take opportunity to expose his vision in play writing. Second, we will focus on Fences (1986), with the aim to probe in the significance of fence building.

\section{I/ An Overview of Wilson's Work}

\section{a- From Poetry to Drama: Black Cultural and Historical Experience in Print}

August Wilson is known as one of the most prominent African American playwrights today; but in reality his writing career was deeply inspired by the rising movement of black consciousness of the 1960s. This social, cultural, and political movement illustrated itself in poetry with more vitality than in other forms of literary production. This is not because poetry was more important than other forms of writings, but simply because it was the genre mostly used to echo the sentiment of Blacks to their cultural and historical heritage. For Wilson, two main events stimulated his poetical creativity. First, his involvement in the Black Power Movement which was the political expression of black consciousness; and second, his hearing of a record by black singer Bessie Smith, in 1965 which, he said, triggered his awareness that "I was a representative of a culture and the carrier of some very valuable antecedents",

These two events, and especially his connection with the black revolutionary aesthetic, inspired his writing of poems he dedicated to the leaders of the movement. One of these titles is "For Malcolm X and Others" which appeared in Negro Digest in September 1969; and another one devoted to the singer was entitled "Bessie" and got published in Black Lines in the summer of 1971. In 1973, Wilson wrote "Morning Statement", a poem he often cited as evidence of his mastery of his craft, and his poem "Theme One: The Variations" was included in the anthology The Poetry of Black America (1973).

During this time of poetic writing, Wilson also collaborated in drama projects. For example, he helped found the Black Horizons Theatre Company in Pittsburgh. But it was his move to St Paul, Minnesota in the early 1970s which served as a catalyst, permitting his skills as a dramatist to come to the fore. "St Paul" he said, "was a different environment from Pittsburgh". (Hilary DeVries, 1989, 25) Still, Wilson did not conceive of himself as a playwright until he received the first of several writing grants. After submitting an earlier play Jitney to Minneapolis's playwrights Center, he was granted a Jerome Foundation Fellowship in the 1970s. "I walked in and there were 16 playwrights," Wilson remembers about that grant. "It was the first time I had dinner with other playwrights. It was the first time I began to think of myself as one"3. This grant, two hundred dollars a month for a year, afforded Wilson the opportunity to re-work a previously written one-act play about a blues recording session into what became the full-length Ma Rainey, his first play which was accepted by the O'Neill Theatre center. When this play opened on Broadway at the Cort Theatre in 1984, it brought Wilson critical acclaim and launched his theatrical career.

Wilson published four other plays -Fences (1986), Joe Turner's Come and Gone (1984), The Piano Lesson (1990), Two Trains Running (1989) - which contributed to the confirmation of his skill as well as his fame on the national and international scene of drama. In 1988, Wilson became the first black dramatist to have two plays running concurrently on Broadway: Fences and Joe Turner.

\section{b- An Innovative Voice in Drama:-}

When we consider the particular circumstances that determine the development of Drama in black artistic expression, August Wilson appeared as an exceptional playwright. Challenging American social and political norms, Wilson wanted to make of his theatrical artistry, one that expresses a totally new vision. First, because he had a potential in writing poetry, he used this competence as venue for play writing. In conditions marked by stereotypes and editorial marginality, the form of literary expression which had served to frame Blacks' skill in art was worth using to survive racist censorship.

2 - Hilary DeVries, “The Drama of August Wilson”, Dialogue, n 11 1989, pp. 24

3 - Bonnie Lyons, George Plimpton, “August Wilson, The Art of Theater”, The Paris Review, n 14, Winter 1999, 13-19 
The second major impetus to Wilson's theatrical performance was the growing consciousness about black culture and history in the 1960s. In the boiling period of black consciousness, literature was the principal vehicle of the black voice in the American society. And for writers like Wilson, the main instrument which gave expression to this voice was black traditional culture and heritage. Wilson described his artistic agenda as an attempt to concretize black American tradition, to demonstrate how that tradition "can sustain a man once he has left his father's house" . Indeed the theme that surges through his work is the need for black Americans to forge anew their identity, an identity that is at once African and American. And the main venue for this identity to blossom is in literary works where Wilson illustrated himself through such pioneer pieces as Rite of Passage, Recycle, and The Homecoming most of which were unpublished until the 1980s. Showing his concern for incorporating traditional black art forms and the lives of African American icons into his work, these early works were the ones which sharpened Wilson's skills into making his most serious plays like Ma Rainey, Fences, and Joe Turner. In 1977, Wilson wrote Black Bart and the Sacred Hills, a musical satire based on a group of poems about an outlaw of the Old West. Most critics consider this to be Wilson's serious theatrical debut; the play was produced in St Paul (Minnesota) in 1981.

Apart from these early works, the next major plays function according to a systematic project: each of them is set in a different decade starting from 1900 to the late $20^{\text {th }}$ century. The idea, to paraphrase his vision about this writing project, is to take each decade and look back at one of the most important question that Blacks are confronted with, write a play about it. "Put them together", he says "and you have a history" (Bonnie Lyons, 1990, p.15). It is such a history that shapes each of the plays in what is known as "century cycle" or "ten-play cycle". For the purpose of concision, we will give an overview of the most common of these plays.

Ma Rainey's Black Bottom (1982), the first of this ten-play cycle was the real work of art which established Wilson's fame as a writer and a playwright. Set in the 1920s, the play looks at the economic exploitation of black musicians by white record companies and at the ways in which victims of racism were forced to direct their rage to each other rather than at their oppressors. The reading of the book brings out the pertinent question of identity through the notion of responsibility, which is also the core issue in the next books of the author. Concretely, the tension created by the characters' struggle for recognition ends in a violent conclusion. Ma, the recording star, knows the limits of her commercial success, admitting, "It's just like I been a whore". (Ma Rainey, 1982, p.35) The elderly pianist, Toledo, is an African nationalist who argues: "We done sold ourselves to the white man in order to be like him" (Ma Rainey, 1982, p.41). Levee, the headstrong trumpeter, is intent on making it in the white world, on seeing his name in lights. In the impossibility to confront his white oppressor, Levee inexorably takes it against his own people. Wilson describes Levee's condition in a rhetorical question: "How can I live this life in a society that refuses to allow me to contribute to its welfare?" Through this question that Levee puts in the play, one can perceive the notion of participation, the problem of one's place or responsibility in society. In 1984, Ma Rainey (1982) opened on Broadway at the Cort Theatre, bringing Wilson critical acclaim and launching his theatrical career. (Marilyn Elkins, 1997, p.782)

Coming in the third position in the list of Wilson's "Pittsburgh cycle", Joe Turner's Come and Gone (1984) deals with the same question of responsibility which is central to his work. Written in 1984, this play is considered as Wilson's favorite. It deals with the personal and cultural development of slavery and the black migration as one can see their manifestations in Pittsburgh. The desperate situation of people of African descent, trapped in sport and music as the only two possibilities left to them, leads them to turn back to their ancestral heritage as an alternative to failure in American society. As Wilson states, "if black folks would recognize themselves as Africans and not be afraid to respond to the world as Africans, then they could make their contribution to the world as Africans" (Hilary DeVries, 1989, p.24) This is what the protagonist Loomis chooses to do in Joe Turner, and so do the other leading figures in the subsequent plays. The story is set in 1911 and is imbued with African ancestral materials like ghosts, myths and spells, which become the basis for Loomis's search.

The framing of Black's identity is also central in Fences (1986), another important component of the cycle, which is going to be the focus of the next section of this study.

\footnotetext{
4 - Marilyn Elkins, "August Wilson”, The Oxford Companion to African American Literature, New York, Oxford Univ. Press, 1997, 781-783
} 


\section{II/ Fences (1986): Protection and Responsibility in African American Community a- The Metaphor of Separation from External Assaults}

Fences (1986) is considered as the most popular of Wilson's plays, because of the huge critical response it received and the number of prizes it won compared to Joe Turner (1984) or The Piano Lesson (1990) which drew no less critical acclaim. But this multiple prize winning play chiefly consolidated its supremacy in the American and world theatre readership with the theme and the main setting of the story it represents: the heating period of the late 1950s and early 1960s. Perhaps the historical setting, that's to say, the increasing tension of the decade was influential in keeping Fences (1986) to the "hit" of the American theatrical production, more than the Pulitzer, or the John Gassner Outer Critics' Circle Award for Best American Playwright, to cite only two of the high ranked prizes the play brought to Wilson. And from this point of view, the title Fences is evocative of the social situation since it illustrates the fracture that existed in the American society in 1957, a society symbolized by the small unnamed city that bears all the traits of a Pittsburgh local town.

Troy Maxson, an African American garbage man, former prisoner and baseball player is in constant opposition with his family members, especially his sons who want to seize the only opportunity that the racially-ostracized society offered to them in the late 1950s. Cory, his younger son is offered a scholarship to integrate a training school for a football career. But Troy refuses to sign the papers because he is skeptical about the future of a black sportsman in the racist American social setting. As the type of father-son relationship crystallizes the story of Wilson's play, the reader - or spectator - notices that this relationship is strongly influenced by the racial tension that bowls along the streets during the late 1950s. As the play opens on a ritual scene of talk and drink between Troy Maxson and Bono his colleague and friend on a Friday night, it is the issue of racial inequality which dominates the conversion between the two friends:

Troy: I ain't worried about them firing me. They gonna fire me cause I asked a question? That's all I did. I went to Mr. Rand and asked him, "why?" why you got the white mens driving and the colored lifting?" Told him, "what's the matter, don't I count? You think only white fellows got sense enough to drive a truck. How come you got all whites driving and the colored lifting? $\mathrm{He}$ told me "take it to the union." Well, hell, that's what I done! (Fences, 2-3)

At a moment when the movement of desegregation had broken out with such resistant actions as Rosa Park's refusal to give her sit to white voyagers in Alabama public transport company in 1955, Troy Maxson's claim for equality in the distribution of tasks in the garbage company captures the general atmosphere of racial suspicion and vigilance. As a worker and active militant in their corporate union, Troy wants equal treatment. He protests against the fact that only white workers are posted in the position of driving the truck while blacks are assigned to lifting the rubbish. It is this injustice, basically nourished by racist hatred, which pushes him to complete the building of a fence around his house. The ancient two-story brick house Troy lives in with his family is "partially fenced" which means that the small dirty yard and his household are clearly exposed to the outward world. This seems absolutely unacceptable to Troy because of the potential danger the outside racist world represents to his family.

As an ex-con man and former player in the Negro Baseball League, Troy sees his life as a failure, because the racism in American institutions did not allow him to give full expression to his performances and benefit from his status as talented sportsman. Frustrated, he is not ready to expose his household to the same assault from that world; this is, to a large extent, the significance of this fence he is trying to build in his partially protected yard. The first person of the family that he intends to protect from the outside racist assault is Cory, his youngest son. Cory has been recruited in a football school and Troy is supposed to sign the paper authorizing him to join the team. To Rose, Troy's wife, who has been playing the mediator in convincing him to sign the papers of the recruiter, he replies: "The white man ain't gonna let him get nowhere with that football" (p.8). Later, upon her insistence, he burst out almost breathlessly:

I don't want him to be like me! I want him to move as far away from my life as he can get. You the only decent thing that ever happen to me. I wish him that. But I don't wish him a thing else from my life. I decided seventeen years ago that boy wasn't getting involved in no sports. Not after what they did to me in the sports. (Fences, p.39)

The experience that Troy had had as a baseball player was visibly painful from what we can read of his answers to Rose. He admits that though he had been a talented player in the past, and even if he was as good as the most 
talented players like Babe Ruth and Josh Gibson, sports hadn't given him "a pot to piss in or a window to throw it out of' (p.9). This poor experience was caused, according to him, by the racist sentiment of white sports leaders who would not give colored players the same chance they gave whites: "they got colored on the team and don't use them. ...All them teams the same" (p.34) For Troy, thus, it is time to protect the "only decent thing that ever happen to [him]", and it becomes clear that he will use the fence which is being erected as protection, even if he is not fundamentally aware of Rose's motives for building it.

And yet there seems to be no doubt about the role of that fence as Bono unequivocally states: "Some people build fences to keep people out... and other people build fences to keep people in. Rose wants to hold on to you all. She loves you" (p.61). While the fence is supposed to protect Troy's family from white world racism, Bono senses it to be a barrier that is meant to safeguard Rose's love. This perspective developed by Troy's friend gives more than a symbolic character to the fence since Troy has been unfaithful to his wife and he is aware of it. Whenever he has had time to mention it with his friend, Bono has warned him about the possible danger of his unfaithful relation with Alberta, Troy's lover. Having the fence built is for Rose a kind of premonition, the necessity to anticipate an unpleasant interference in her marital life with Troy. Unfortunately, the completion of the fence comes up late, because Troy has already been with his lover for a long time and by the moment he reveals it to Rose, it is to inform her that he is "gonna be a daddy" (p.66) If for Rose the significance of the fence was the protection from a love intruder in her marriage, the fact that Troy announces he's going to have a baby with another woman is a total disillusion, which she expresses in moving terms:

I done tried to be everything a wife should be. Everything a wife could be. Been married eighteen years and I got to live to see the day you tell me you been seeing another woman and done fathered a child by her. And you know I ain't never wanted no half nothing in my family. (pp.67-68)

As one can see, the building of the fence has not saved Rose's love with her husband from an outside intrusion. As a result, she is totally left in disarray. Her statement above shows how disappointed she feels toward a man to whom she has devoted her life and who, in return, has had to do nothing but "lay in bed with another woman... and then bring it home to me" (p.70).

Even if Rose is right to blame Troy for his unfaithfulness and to accuse him for being ungrateful regarding the sacrifices she has made for their love, a careful examination of the story can also instruct the reader about the fact that such unfortunate intrusion could not be avoided, given the lack of vigilance form her. For, while she has wanted the fence to be completed and kept calling on her husband and Cory to work on it, the completion has always been deferred by Troy. One has to look in the lines of the following answer he gives her when she draws his attention to it: "I'm gonna walk down to Taylors'. Listen to the ball game. I'll be back in a bit. I'll work on it when I get back" (p.28). If the lack of vigilance has been disastrous for Rose's family with the intrusion of a rival in her home, the fact of postponing the building turns out even bitter to Troy himself. Indeed, not long after he informs Rose about his relation with Alberta, he is in turn informed that she has died in childbirth. Inconsolable, his mourning reveals the real significance of the fence for him:

Alright... Mr. Death. See now... I'm gonna tell you what I'm gonna do. I'm gonna take and build me a fence around this yard. See? I'm gonna build me a fence around what belongs to me. And then I want you to stay on the other side. See? You stay other there until you're ready for me. Then you come on. Bring your army. Bring your sickle. Bring your wrestling clothes. I ain’t gonna fall down on my vigilance this time. You ain't gonna sneak up on me no more. When you ready for me... When the top of your list say Troy Maxson... (p.77)

Troy's mourning is nothing but an elegy; it is a sad expression of pain caused by death, a pain which has the effect of triggering a deep sentiment of defiance toward death itself as personified in his words. Hurt and dispossessed of his lover, Troy scowls his grief and challenges death with the fence he intends to erect in order to keep him "on the other side".

\section{b- The Fence of the African American's Responsibility}

More important than simply protecting the family from outward adversities is what the fence allows Troy to do, precisely in terms of charting an identity and a destiny for Maxson family which, in Wilson's play, represents the African American community. The issue of identity or destiny of the African American is a crucial issue in Wilson's 
artistic work; and especially in Fences (1986) it is raised in the following terms: Is there an alternative to music and sports, the only outlets for the black in a racist American society? It is this question that sets the conflict between Troy Maxson, the main protagonist and father of the family, and Cory his youngest son.

In the story, indeed, Troy is portrayed as an uncompromising opponent to sports, because he considers himself as a living proof of this choice, which has earned him nothing, not even "a pot to piss in or a window to throw it out of" as he will often say. This is why he refuses to let Cory engage in the same career. And even if Cory refuses to listen to his father's advice and holds on to his enrolment in a football school, Troy's answer is evocative of what he suggests concerning the real destiny of his family in the racist social environment: Neither a football career nor the music of Lyons, the elder brother of Cory because they are the products of white racist ruling of American society. Troy rather insists on hard work, which he urges his children to embrace. Whenever one of them comes to ask him something, his answer is invariably negative. For example, when Cory entreats him to sign the paper of the football recruiter, he scowls at him saying: "The white man ain't gonna let you get nowhere with that football noway. You go on and get your book-learning so you can work yourself up in the A\&P or learn how to fix cars or build houses or something" (p.35).

To be trained to secure a job that helps everyone to take care of themselves is what matters for Troy. After all, he has done pretty well in supporting his family as a worker in the garbage-collect company of the town. Even if it is a lower job, it has permitted him to secure the minimum for them and he is ready to boast about it to Cory when answering his objection about his attitude to him:

Troy: You eat everyday [?]

Cory: Yessir!

Troy: You got a roof over your head [?]

Cory: Yessir!

Troy: Why you think that is?

Cory: (Hesitant) Cause you like me.

Troy: Like you? I go out of here every morning... bust my butt... putting up with them crackers every day ... cause I like you? You about the biggest fool I ever saw. (Pause)

It's my job. It's my responsibility! You understand that? A man got to take care of his family. ... Mr Rand don't give me money come payday cause he likes me. He had to gives me cause he owe me. ... (pp.37-38)

The attention that one has toward one's family and, precisely, the determination to provide for their needs is the measure of one's responsibility in society. This responsibility is valued only by holding a job according to Troy. Linked together, these two notions are central in Fences (1986), which appears, thus, as a play in which the reader discovers a new framing of the African American identity. If responsibility is the most important thing for a man and, if for Troy it is nourished by work rather than music and sports, then one can say that it is the measure of one's identity. Even if Wilson does not explicitly express his preference for his protagonist's choice, the fact that Troy progresses from the position of simple garbage collector to position of driver in the company shows that other opportunities are opened to African Americans, precisely on the field of job market characterized by hard work and competition.

This perspective on work and responsibility developed in Fences (1986) is essential in the works of most of contemporary African American intellectuals like August Wilson and Shelby Steele, to cite the most popular of them. The point of contention in the debate is the association which is commonly drawn between African Americans and their racial heritage. Music and sports, for instance, described as the only outlets for people of African descent, are the expression of racial stigmatization. It is no wonder, then, that Wilson's protagonist rejects them.

Still, Wilson does not totally break with the African American's past. For example, in spite of Troy's refusal of Lyons' music, he is constantly tuning a song which plunges him back to his past:

Here it rings! Here it rings

Had an old dog his name was Blue

You know Blue was mighty true

You know Blue was a good old dog

Blue trees a possum in a hollow log 
You know from that he was a good old dog (p.82)

Poetic in its rhetoric framing, this song which chants Troy's nostalgia for his "blue dog", also sounds like a blues that is regularly tuned to help him find his wholeness. In the end, Troy appears as a person with an ambivalent identity, an identity which cumulates the American values and the values of the African ancestral heritage. It is this double consciousness that Wilson articulates in the following statement: "if black folks would recognize themselves as Africans and not be afraid to respond to the world as Africans, then they could make their contribution to the world as Africans" (Hilary DeVries, 1989, p.24).

Sharing the same vision of responsibility and work as Wilson, Shelby Steele, has also written a lot on the issue of identity; but he is rather attached to American values of work, individual initiative and property ownership. As he writes in "On Being Black and Middle Class", these values are better that anything else for a respectable African American personality:

Hard work, education, individual initiative, stable family life, property ownership -these have always been the means by which ethnic groups have moved ahead in America. Regardless of past and present victimization, these "laws" of advancement apply absolutely to black Americans also. There is no getting around this. What we need is a form of racial identity that energizes the individual by putting him in touch with both his possibilities and his responsibilities. (Steele, 108)

Even if Steele talks about "racial identity", it is clear that the form of identity to which he refers has nothing to do with the race; it rather has to do with values which contribute to the promotion of a democratic and equalitarian society. Expressed in terms of work, education, individual initiative, or private ownership, these values shape, according to Steele, the notion of responsibility which African American intellectuals praise so much today.

Whether we are in a radically liberal perspective or in a double conscious worldview, the question of identity takes a new articulation in contemporary African American artistic production like in the drama of August Wilson. Fences (1986) is one among the theatrical works written by this playwright which charts a new definition to it.

\section{Conclusion:-}

To learn about the life and work of playwright August Wilson is also to learn about the place of the Black in American theatrical development. For a long time, this place has been, marginal, as we showed in "The African American Theatrical Expression", a precedent work published in Particip'Action (2107) ${ }^{5}$. Because of the negative impact of some major phenomena like slavery, and the stereotypes that it contributed to develop about the image of people African descent, it has been historically difficult for African American artists to contribute to drama as easily as they did in other artistic genres. And yet, thanks to his artistic genius, playwright August Wilson has brought African American drama out of its historical lethargy.

Using his creative potentials as a venue, and notably his skills as a poet, Wilson has revitalized the public expression of African American drama since the black revolutionary movement of the 1960s. For example, he assigned himself the challenging task to "sketch the Black experience in the $20^{\text {th }}$ century and raise consciousness through theater and echo the poetry in the everyday language of black America" (Bonnie Lyons et al., 1999, p.17). This exercise resulted in the writing of the ten-play series commonly known as "century cycle" or "ten-play cycle", and of which Fences (1986) is a significant component. In fact, these played are the place where Wilson accomplishes one of his longawaited goals: the shaping of a new identity for African Americans through drama.

This task has also been the concern of many other writers of African descent, principally those who constitute the contemporary middle class of the community and of which essayist Shelby Steele can be considered as the spokesperson. In a way because the African Americans of the popular class made abundant use of the black ancestral culture and racial heritage in the past, chiefly in claiming for rights and power during the Civil Rights movement, the middle class intellectuals of the community have always been reluctant to identify themselves with them. Worse, they have literally rejected what Shelby considers as a victim's identity. According to him this identity

5- Kouamé SAYNI, ibidem, p.100 
is "devastating" for the image of African Americans in today's American society characterized by values of work and competition.

This study has been an opportunity to cast a look at Wilson's contribution to the framing of this new identity. After a quick but critical overview of his life and career, our exercise has focused on Fences (1986) through which Wilson tailors the main rhetoric of African American identity. Based on the building -more precisely, the completion- of the half-fenced home for the family of Troy Maxson, a frustrated garbage collector, the play points out the traumatizing heritage of racism in 1950 American society. Because racism led him to failure in sports, Troy cannot allow his family members to choose the same career, presented with music as the only two possibilities left to African Americans. A critical analysis of the tension that rises from the opposite positions in the family has given us an occasion to determine Wilson's definition of his new vision for the destiny of the Black in contemporary American society. Relatively different from Steele's perspective, it is a rather mitigated vision based on work and ancestral heritage.

\section{Bibliography:-}

1. Wilson, August. Fences, New York, Penguin Books, 1986

2. Wilson, August. Ma Rainey's Black Bottom, New York, New American Library, 1982

3. Wilson, August. Joe Turner's Come and Gone, New York, Samuel French, Inc. 1990

4. Lyons, Bonnie. Plimpton, George. "August Wilson, The Art of Theater”, The Paris Review, n 14, Winter 1999

5. DeVries, Hilary. "The Drama of August Wilson", Dialogue, n 11989

6. Elkins, Marilyn. "August Wilson”, The Oxford Companion to African American Literature, New York, Oxford Univ. Press, 1997

7. Kouamé, SAYNI. "The African American Theatrical Expression in the USA: A Crippled Quest for Identity", Particip'Action, Vol 9, Janvier 2017

8. Steele, Shelby. The Content of our Character: A New Vision of Race in America, New York, Harper Perennial, 1990. 